\title{
DINAMIKA KELOMPOK TANI TERNAK SAPI LM3 DI DESA PINAPALANGKOW KECAMATAN SULUUN TARERAN
}

\author{
Omega Runtunuwu* , B. F. J. Sondakh, B. Rorimpandey dan F.N. S. Oroh \\ Fakultas Peternakan Universitas Sam Ratulangi Manado, 95115
}

\begin{abstract}
ABSTRAK
Peranan masyarakat sangat besar dalam pembangunan peternakan, sehingga pembinaan kelembagaan masyarakat peternak melalui kelompok tani perlu ditingkatkan.Keadaan anggota kelompok tani dapat mempengaruhi kedinamisan kelompok lewat indikator-indikator dinamika yang ada. Terbentuknya dinamika kelompok tani ini diharapkan dapat meningkatkan pendapatan dan kesejatraan setiap anggota kelompok. Penelitian ini bertujuan untuk menganalisis hubungan dinamika dengan pendapatan usaha ternak sapi pada kelompok tani LM3 Model Anugerah di Desa Pinapalangkow Kecamatan Suluun Tareran. Penelitian menggunakan metode survey, dengan penentuan sampel secara total sampling. Hasil analisis korelasi person di peroleh $r_{\text {hitung }}$ sebesar 0,67 yang menunjukan terdapat keeratan hubungan antara dinamika dan pendapatan anggota kelompok. Nilai $r_{\text {hitung }}$ ini menunjukan hubungan antara dinamika dan pendapatan anggota kelompok adalah hubungan positif, yang artinya semakin tinggi pendapatan menyebabkan dinamika kelompok semakin tinggi. Hasil uji statistik menunjukan pendapatan berpengaruh nyata terhadap dinamika kelompok pada tinggkat kepercayaan $95 \%$.
\end{abstract}

Kata Kunci :Dinamika, Kelompok Tani, Pendapatan, Sapi

\section{ABSTRACT}

BEEF CATTLE FARMER GROUP DYNAMICS LM3 DISTRICT IN THE VILLAGE PINAPALANGKOW SULUUN

TARERAN. The role of the community is very large in livestock development, thereby fostering

\footnotetext{
*Korespondensi (corresponding author):
}

Email: omegaruntunuwu@yahoo.com community institutions farmers through farmer groups need to be improved. State farmer group members can affect group dynamics through indicators dynamics. The formation of farmer group dynamics is expected to improve income and the welfare of each member of the farmer group. This study aimed to analyze the dynamics of the relationship with the farmer group operating revenues cattle farmer groups LM3 Model Anugerah in the village of Pinapalangkow in Sub District of Suluun Tareran. The study used a survey method, with sampling method is total sampling. Person correlation analysis results obtained $r_{\text {count }}$ of 0.67 of 0.67 which shows there is a relationship between the dynamics and the income of the group members $r_{\text {count }}$ value shows the relationship between the dynamics and the income of the group is a positive relationship, which means that the higher the income the higher the lead group dynamics. The test results showed a statistically significant effect on the dynamics of income groups at the $95 \%$ confidence level .

Keywords: Dynamics, Farmer Group,Income, Cattle

\section{PENDAHULUAN}

Peranan masyarakat sangat besar dalam pembangunan peternakan, sehingga pembinaan kelembagaan masyarakat peternak baik perorangan ma upun kelompok tani perlu ditingkatkan.Pembinaan kelembagaan petani perlu dilakukan secara berkesinambungan, diarahkan pada perubahan pola pikir petani dalam menerapkan sistem agribisnis. 
Pembinaan kelembagaan petani juga diarahkan untuk menumbuhkembangkan kelompok tani (poktan) dan gabungan kelompok tani (gapoktan) dalam menjalankan fungsinya, serta meningkatkan kapasitas poktan dan gapoktan melalui pengembangan kerjasama dalam bentuk jejaring dan kemitraan (Kementan, 2013).

Kelompok tani merupakan petani yang dibentuk atas dasar kepentingan kesamaan kondisi lingkungan (sosial, ekonomi, sumberdaya) keakraban dan keserasian yang di pimpin oleh seorang ketua (Trimo, 2006). Biasanya jumlah anggota kelompok tani berkisar antara 10-25 orang (Suhardiyono, 1992). Dinamika kelompok tani ialah suatu kelompok yang terdiri dari dua atau lebih individu yang memiliki hubungan psikologis secara jelas antara anggota satu dengan yang lain sebagai pergerakan kelompok menuju ke arah yang lebih maju dan positif. Ternak sapi, khususnya sapi potong merupakan salah satu sumber daya penghasil daging yang memiliki nilai ekonomis tinggi dan penting artinya bagi kehidupan masyarakat (Sugeng, 2008). Kecamatan Suluun Tareran terdapat beberapa kelompok tani ternak salah satu diantaranya kelompok tani LM3 Model Anugerah di desa Pinapalangkow. Luas daerah Desa Pinapalangkow 576,974 Ha dengan jumlah penduduk 1129 jiwa. Jumlah anggota 12 orang yang bergerak di bidang peternakan sapi. Kelompok tani ini berdiri pada tahun 2009 dan hingga saat ini masih aktif. Terbentuknya
Kelompok tani "LM3”Model Anugerah berawal dari kelompok ternak yang anggotaanggotanya sudah memiliki ternak sapi sendiri dan berpengalaman dalam beternak sapi. Kelompok tani “LM3”Model Anugerah merupakan program lanjutan dari Dinas Pertanian dan Peternakan Propinsi Sulawesi Utara Tahun 2009 memperoleh bantuan dana sebesar Rp. 256.000.000,00 yang digunakan dalam pengembangan ternak sapi. Lahan atau kebun yang digunakan merupakan milik dari ketua kelompok sebesar $4 \mathrm{Ha}$.

Manajemen pemeliharaan ternak sapi dilakukan melalui pemberian tanggung jawab pada masing-masing anggota kelompok. Sampai saat ini ternak sapi yang dimiliki kelompok berjumlah 34 ekor. Berdasarkan perkembangan dari kelompok tani tersebut, kemudian kelompok tani ini menjadi kelompok tani "LM3" Model Anugerah setelah dilakukannya seleksi dari beberapa LM3 yang ada di Sulawesi Utara. Ketua kelompok tani "LM3" Model anugerah sebagai ketua asosiasi kelompok tani di Sulawesi Utara.

Terbentuknya kelompok tani ternak ini diharapkan akan meningkatkan pendapatan anggota kelompok tani ternak, hal ini tergantung dari kedinamisan kelompok tersebut. Dari urain diatas tersebut maka perlu dilakukan penelitian untuk mengetahui dinamika kelompok tani, faktor dinamika kelompok tani dan hubungan dinamika kelompok tani dan pendapatan. 


\section{METODE PENELITIAN}

Penelitian ini dilaksanakan di Kabupaten Minahasa Selatan Kecamatan Suluun Tareran desa Pinapalangkow. Survei dilaksanakan mulai tanggal 1 November 2013 sampai tanggal 30 November 2013. Teknik pengumpulan data menggunakan metode survei. Survei adalah suatu proses pengumpulan informasi dari responden pada suatu populasi dengan harapan akan diperoleh data yang akurat dengan menggunakan kuisioner sebagai alat pengumpulan data (Sigarimbun dan Effendi, 1999). Data yang di kumpulkan yaitu data primer dan data sekunder. Penentuan sampel secara total sampling. Definisi konsep variable dan pengukurannya meliputi :

1. Dinamika kelompok tani ialah suatu kelompok yang terdiri dari dua atau lebih individu yang memiliki hubungan psikologis secara jelas antara anggota satu dengan yang lain sebagai pergerakan kelompok menuju ke arah yang lebih maju dan positif. Indikator adanya dinamika kelompok diukur melalui ;

a. Tujuan kelompok ialah gambaran suatu hasil yang di harapkan oleh anggota kelompok untuk dicapai. Pengukurannya melalui pemberian skor atas jawaban dari pertanyaanpertanyaan yang ada dan skor yang diberikan untuk masing-masing pertanyaan yaitu 3, 2 dan 1. Skor tertinggi 12 dan skor terendah adalah 4. Klasifikasi tingkat skornya adalah sebagai berikut.

Rendah: $4-6,6$, Sedang: 6,7 - 9,3, Tinggi: 9,4 - 12

b. Struktur kelompok ialah bentuk hubungan antara individu-individu dalam kelompok sesuai posisi dan peranan masing-masing. Pengukurannya melalui pemberian skor atas jawaban dari pertanyaanpertanyaan yang adadan skor yang di berikan untuk masing-masing pertanyaan yaitu 3, 2 dan 1. Skor tertinggi 9 dan skor terendah adalah 3. Klasifikasi tingkat skornya adalah sebagai berikut.

Rendah : $3-4,9$, Sedang : $5-6,9$, Tinggi : 7 - 9

c. Fungsi tugas diukur melalui pemberian skor atas jawaban dari pertanyaan-pertanyaan yang adadan skor yang di berikan untuk masingmasing pertanyaan yaitu 3, 2 dan 1 . Skor tertinggi 15 dan skor terendah adalah 5. Klasifikasi tingkat skornya adalah sebagai berikut.

Rendah : 5 - 8,3, Sedang : 8,4 11,7, Tinggi : 11,8 - 15

d. Pembinaan kelompok ialah usahausaha apa saja dalam meningkatkan kemampuan kelompok untuk melaksanakan 
kegiatan sesuai dengan fungsi dan perannya dalam kelompok. Pengukurannya melalui pemberian skor atas jawaban dari pertanyaanpertanyaan yang adadan skor yang di berikan untuk masing-masing pertanyaan yaitu 3,2 dan 1. Skor tertinggi 12 dan skor terendah adalah 4. Klasifikasi tingkat skornya adalah sebagai berikut.

Rendah : $4-6,6$, Sedang : 6,7 9,3, Tinggi : 9,4 - 12

e. Kekompakan kelompok menunjukkan tingkat rasa untuk tetap tinggal dalam kelompok. Pengukurannya melalui pemberian skor atas jawaban dari pertanyaanpertanyaan yang ada dan skor yang di berikan untuk masing-masing pertanyaan yaitu 3, 2 dan 1. Skor tertinggi 12 dan skor terendah adalah 4. Klasifikasi tingkat skornya adalah sebagai berikut.

Rendah : 4 - 6,6, Sedang : 6,7 9,3, Tinggi : 9,4 - 12

f. Suasana kelompok diukur melalui pemberian skor atas jawaban dari pertanyaan-pertanyaan yang adadan skor yang di berikan untuk masingmasing pertanyaan yaitu 3, 2 dan 1 . Skor tertinggi 12 dan skor terendah adalah 4. Klasifikasi tingkat skornya adalah sebagai berikut.
Rendah : 4 - 6,6, Sedang : 6,7 - 9,3, Tinggi : 9,4 - 12

g. Tekanan pada kelompok dimaksudkan adanya tekanantekanan dalam kelompok yang dapat menimbulkan ketegangan, dengan adanya ketegangan akan timbul dorongan untuk mempertahankan tujuan kelompok. Pengukurannya melalui pemberian skor atas jawaban dari pertanyaanpertanyaan yang adadan skor yang di berikan untuk masing-masing pertanyaan yaitu 3, 2 dan 1. Skor tertinggi 9 dan skor terendah adalah 3. Klasifikasi tingkat skornya adalah sebagai berikut.

Rendah : $3-4,9$, Sedang : $5-6,9$, Tinggi : 7 - 9

h. Efektifitas kelompok ialah keberhasilan dalam melaksanakan tugas-tugas kelompok dalam mencapai tujuan. Pengukurannya melalui pemberian skor atas jawaban dari pertanyaanpertanyaan yang adadan skor yang di berikan untuk masing-masing pertanyaan yaitu 3, 2 dan 1. Skor tertinggi 15 dan skor terendah adalah 5. Klasifikasi tingkat skornya adalah sebagai berikut.

Rendah : 5 - 8,3, Sedang : 8,4 11,7, Tinggi : $11,8-15$ 
i. Penyelesain konflik ialah suatu cara penyelesain yang terjadi dalam kegiatan kelompok. Pengukurannya melalui pemberian skor atas jawaban dari pertanyaanpertanyaan yang adadan skor yang di berikan untuk masing-masing pertanyaan yaitu 3, 2 dan 1. Skor tertinggi 3 dan skor terendah adalah 1. Klasifikasi tingkat skornya adalah sebagai berikut.

Rendah : 1 - 1,6, Sedang : 1,7 2,3, Tinggi : 2,4 - 3

j. Perencanaan diukur melalui pemberian skor atas jawaban dari pertanyaan-pertanyaan yang ada dan skor yang di berikan untuk masing-masing pertanyaan yaitu 3 , 2 dan 1. Skor tertinggi 6 dan skor terendah adalah 2. Klasifikasi tingkat skornya adalah sebagai berikut.

Rendah : 2 - 3,3, Sedang : 3,44,7, Tinggi : 4,8 - 6

k. Pengawasan ialah diukur melalui pemberian skor atas jawaban dari pertanyaan-pertanyaan yang ada dan skor yang di berikan untuk masing-masing pertanyaan yaitu 3 , 2 dan 1. Skor tertinggi 3 dan skor terendah adalah 1. Klasifikasi tingkat skornya adalah sebagai berikut.
Rendah : 1 - 1,6, Sedang :1,7 2,3, Tinggi : 2,4 - 3

1. Hak dan kewajiban anggota diukur melalui pemberian skor atas jawaban dari pertanyaanpertanyaan yang adadan skor yang di berikan untuk masing-masing pertanyaan yaitu 3, 2 dan 1 . Skor tertinggi 6 dan skor terendah adalah 2. Klasifikasi tingkat skornya adalah sebagai berikut.

Rendah : 2 - 3,3, Sedang :3,4 4,7, Tinggi :4,8 - 6

m. Hak dan kewajiban pimpinan/pengurus diukur melalui pemberian skor atas jawaban dari pertanyaan-pertanyaan yang adadan skor yang di berikan untuk masing-masing pertanyaan yaitu 3, 2 dan 1. Skor tertinggi 6 dan skor terendah adalah 2. Klasifikasi tingkat skornya adalah sebagai berikut.

Rendah : 2 - 3,3, Sedang : 3,44,7, Tinggim : 4,8 - 6

Pengukuran dinamika yaitu pemberian skor atas setiap jawaban dari pertanyaan yang diberikan disaat wawancara dengan responden kemudian skor yang diberikan dijumlahkan. Skor yang diberikan untuk masing-masing pertanyaan adalah 3 ; 2; dan 1 . Skor tertinggi 120 dan terendah adalah 40. Jumlah 
pertanyaan 40 dengan klasifikasi atau skornya

$$
\begin{aligned}
\text { yaitu } \frac{120-40}{3} & =26,7 \\
& >41-67,6=\text { rendah } \\
& >67,7-94,3=\text { sedang } \\
& >94,4-120=\text { tinggi }
\end{aligned}
$$

2. Pendapatan usaha ternak sapi ialah nilai jual ternak sapi dihitung dalam satuan rupiah per tahun.

Data yang di peroleh dari hasil penelitian di analisis dengan menggunakan metode deskriptif (Nawawi, 1995).

Dalam penelitian ini untuk mengukur sikap, pendapat, dan persepsi seseorang atau kelompok orang tentang fenomena sosial digunakan skala Likert. Dengan Skala Likert, variable yang akan diukur dijabarkan menjadi indikator variabel.

Analisis yang akan digunakan untuk mengukur hubungan antara dinamika kelompok dengan pendapatan usaha ternak sapi kelompok menggunakan pendekatan analisis korelasi pearson. Korelasi pearson dirumuskan sebagai berikut :

$$
r=\frac{N \cdot \sum X Y-\left(\sum X\right) \cdot\left(\sum Y\right)}{\sqrt{\left\{N \cdot \sum X^{2}-\left(\sum X\right)^{2}\right\}} \cdot\left\{N \cdot \sum Y^{2}-\left(\sum Y\right)^{2}\right\}}
$$

Untuk pengujian signifikansi $r$ (korelasi pearson) digunakan uji-t dengan rumus :

$$
t=\frac{r \sqrt{N-1}}{\sqrt{1-r^{2}}}
$$

Apabila nilai t tabel lebih kecil dari nilai t hitung berarti hipotesis Ho diterima dan hipotesis $\mathrm{H} 1$ di tolak, sedangkan apabila nilai $\mathrm{t}$ hitung lebih besar dari nilai t tabel berarti hipotesis H1 diterima dan hipotesis Ho di tolak.

\section{HASIL DAN PEMBAHASAN}

\section{Tujuan Kelompok}

Tujuan kelompok ialah gambaran suatu hasil yang diharapkan oleh anggota kelompok untuk dicapai.Jumlah responden sesuai dengan tingkat pencapain kelompok dapat dilihat pada Tabel 1 .

Data Tabel 1 menunjukkan bahwa semua responden memberikan jawaban dengan kategori tinggi, yaitu $100 \%$ Hal ini membuktikan seluruh anggota kelompok setuju dengan pertanyaan-pertanyaan bahwa setiap anggota. Ini membuktikan bahwa seluruh anggota kelompok tani berkeinginan agar setiap pelaksanaan kegiatan yang ada dalam kelompok tani dapat mencapai tujuan.

Tabel 1. Jumlah Responden Sesuai dengan Tingkat Pencapaian Kelompok

\begin{tabular}{ccc}
\hline Tujuan Kelompok & Jumlah Responden & Prosentase \% \\
\hline Tinggi & 12 & 100 \\
Sedang & - & 0 \\
Rendah & - & 0 \\
\hline Jumlah & 12 & 100 \\
\hline
\end{tabular}


Tabel 2. Jumlah Responden menurut Tingkat Struktur Kelompok

\begin{tabular}{ccc}
\hline 'Struktur kelompok & Jumlah Responden & Prosentase \% \\
\hline Tinggi & 12 & 100 \\
Sedang & - & 0 \\
Rendah & - & 0 \\
\hline Jumlah & 12 & 100 \\
\hline
\end{tabular}

Tabel 3. Jumlah Responden Menurut fungsi dan tugas kelompok

\begin{tabular}{ccc}
\hline Fungsi dan tugas Kelompok & Jumlah Responden & Prosentase \% \\
\hline Tinggi & 11 & 91,67 \\
Sedang & 1 & 8,34 \\
Rendah & - & 0 \\
\hline Jumlah & 12 & 100 \\
\hline
\end{tabular}

\section{Struktur Kelompok}

Struktur kelompok juga ialah bentuk hubungan antara individu-individu dalam kelompok sesuai posisi dan peranan masingmasing. Jumlah responden menurut tingkat struktur kelompok dapat dilihat pada Tabel 2. struktur kelompok dapat dilihat pada Tabel 2. Tabel 2 menunjukkan bahwa seluruh responden berada pada tingkat struktur kelompok yang kategorinya tinggi, yakni $100 \%$ hal ini menunjukan bahwa seluruh anggota kelompok melakukan pembagian tugas kerja secara merata dengan kemampuan, peranan dan posisi masing-masing, struktur komunikasi antara pimpinan dan anggota terjalin dan berlangsung dengan baik, dan selalu melaksanakan pertemuan untuk membahas tentang perkembangan dan masalah yang terjadi dalam kelompok. Sesuai dengan pendapat Togatorop (1986), yang mengatakan bahwa struktur tugas harus sesuai dengan tujuan kelompok sehingga dapat menjamin dinamika kelompok yang maksimal.

\section{Fungsi dan Tugas Kelompok}

Seperti yang dikemukakan oleh Hakman dalam Mardikanto (1996) fungsi dan tugas kelompok yaitu seperangkat tugas yang harus dilaksanakan oleh setiap anggota kelompok sesuai dengan fungsi masingmasing sesuai dengan kedudukannya dalam kelompok.Jumlah responden menurut fungsi dan tugas kelompok dapat dilihat pada Tabel 3. Hasil Penelitian pada Tabel 3 menujukkan bahwa jawaban yang diberikan oleh responden atau anggota kelompok tani yang berada pada tingkat tertinggi adalah 91,67\%, sedangkan pada tingkat sedang adalah $8,34 \%$, dan pada tingkat yang rendah adalah $0 \%$, hal ini menunjukan bahwa ada anggota yang jarang melaksanakan tugas dan fungsi yang sudah ditetapkan, dan hampir seluruh anggota kelompok melaksanakan tugas dan fungsinya masing-masing sesuai dengan pertanyaanpertanyaan diatas. 
Tabel 4. Jumlah Responden Menurut Tingkat Pembinaan Kelompok

\begin{tabular}{ccc}
\hline Pembinaan Kelompok & Jumlah Responden & Prosentase \% \\
\hline Tinggi & 12 & 100 \\
Sedang & - & 0 \\
Rendah & - & 0 \\
\hline Jumlah & 12 & 100 \\
\hline
\end{tabular}

Tabel 5. Jumlah Responden Menurut Tingkat Kekompakan Kelompok

\begin{tabular}{ccc}
\hline kekompakan Kelompok & Jumlah Responden & Prosentase \% \\
\hline Tinggi & 10 & 83,34 \\
Sedang & 2 & 16,67 \\
Rendah & - & 0 \\
\hline Jumlah & 12 & 100 \\
\hline
\end{tabular}

\section{Pembinaan Kelompok}

Pembinaan kelompok ialah usahausaha apa saja dalam meningkatkan kemampuan kelompok untuk melaksanakan kegiatan sesuai dengan fungsi dan perannya dalam kelompok.Jumlah responden menurut tingkat pembinaan kelompok dapat dilihat pada Tabel 4. Hasil penelitian menunjukkan bahwa jawaban kategori tinggi sebanyak $100 \%$, dan kategori sedang dan rendah masing-masing $0 \%$. Hal ini menunjukan bahwa seluruh responden sering mendapatkan pembinaan atau mengikuti pembinaan baik dari penyuluh yang ada maupun dari ketua kelompok tani tersebut.

\section{Kekompakan Kelompok}

Menurut Krech dalam Mardikanto (1996), kekompakan kelompok diartikan sebagai rasa keterkaitan anggota kelompok terhadap kelompoknya. Jelasnya dapat dilihat pada Tabel 5. Berdasarkan Tabel 5 terlihat bahwa, responden berada pada tingkat kekompakkan yang tinggi $83,34 \%$, dan rendah pada kategori kekompakan yang sedang yaitu $16,67 \%$. Berdasarkan hasil penelitian diperoleh bahwa pada umumnya anggota aktif dalam setiap pertemuan kelompok.

\section{Suasana Kelompok}

Suasana kelompok ialah keadaan moral, sikap dan perasaan bersemangat atau apatis yang ada dalam kelompok, suasana kelompok yang baik bila anggotanya merasa saling menerima, saling menghargai, saling mempercayai dan bersahabat.Jumlah responden menurut tingkat suasana kelompok dapat dilihat pada Tabel 6 . 
Tabel 6. Jumlah Responden Menurut Tingkat Suasana Kelompok

\begin{tabular}{ccc}
\hline Suasana Kelompok & Jumlah Responden & Prosentase \% \\
\hline Tinggi & 12 & 100 \\
Sedang & - & - \\
Rendah & - & - \\
\hline Jumlah & 12 & 100 \\
\hline
\end{tabular}

Hasil penelitian menunjukan bahwa jawaban kategori tinggi mencapai 100\%, Hal ini membuktikan bahwa seluruh anggota kelompok mampu membuat suasana yang ada dalam suatu kelompok dikatakan menarik dan ada rasa persahabatan, kekeluargaan antar.

\section{Tekanan pada kelompok}

Jumlah responden menurut tingkat tekanan pada kelompok dapat dilihat pada Tabel 7. Hasil penelitian menunjukan bahwa jawaban pada kategori tinggi sebesar 33,34\% pada kategori sedang 66,67\%, dan kategori rendah 0\%. Hal ini menunjukan bahwa sebagian anggota kelompok sering mendapat tekanan baik dari pemerintah/pendamping maupun pimpinan kelompok tani tersebut.

\section{Efektifitas Kelompok}

Efektifitas kelompok yaitu keberhasilan kelompok untuk mencapai tujuannya, yang dapat dilihat pada tercapainya keadaan atau perubahan-perubahan (fisik maupun non fisik) yang memuaskan anggotanya.Jumlah responden menurut tingkat efektifitas kelompok dapat dilihat pada Tabel 8.

Tabel 7. Jumlah Responden Menurut Tingkat Tekanan pada Kelompok

\begin{tabular}{ccc}
\hline Tekanan pada Kelompok & Jumlah Responden & Prosentase \% \\
\hline Tinggi & 4 & 33,34 \\
Sedang & 8 & 66,67 \\
Rendah & - & 0 \\
\hline Jumlah & 12 & 100 \\
\hline
\end{tabular}

Tabel 8. Jumlah Responden Menurut Tingkat Efektifitas Kelompok

\begin{tabular}{ccc}
\hline Efektifitas Kelompok & Jumlah Responden & Prosentase \% \\
\hline Tinggi & 12 & 100 \\
Sedang & - & 0 \\
Rendah & - & 0 \\
\hline Jumlah & 12 & 100 \\
\hline
\end{tabular}


Hasil penelitian ini menunjukan seluruh responden berada pada jawaban kategori tinggi mencapai $100 \%$. Hal ini menunjukan bahwa efektifitas dari kelompok tani tersebut merasa nyaman dan ada kepuasan terhadap hasil yang dicapai oleh kelompok tersebut lewat kegiatan-kegiatan yang berlangsung dikelompok itu sendiri.

\section{Penyelesain Konflik}

Penyelesain konflik ialah suatu cara penyelesain yang terjadi dalam kegiatan kelompok. Jumlah responden menurut tingkat penyelesain konflik dapat dilihat pada Tabel 9. Berdasarkan Tabel 9 hasil penelitian menunjukan bahwa seluruh anggota kelompok tani berada pada kategori tinggi dengan prosentase mencapai $100 \%$.

\section{Perencanaan kelompok}

Perencanaan kelompok ialah suatu bentuk perencanaan yang diperoleh melalui kesepakatan atau musyawarah bersama seluruh anggota kelompok tani dalam pengelolaan/manajemen ternak sapi. Jumlah responden menurut tingkat perencanaan kelompok dapat dilihat pada Tabel 10. Dari Tabel 10 membuktikan bahwa seluruh anggota kelompok berada pada kategori tinggi dengan prosentase mencapai $100 \%$.

Tabel 9. Jumlah Responden Menurut Tingkat Penyelesain Kelompok

\begin{tabular}{ccc}
\hline Penyelesain konflik & Jumlah Responden & Prosentase \% \\
\hline Tinggi & 12 & 100 \\
Sedang & - & 0 \\
Rendah & - & 0 \\
\hline Jumlah & 12 & 100 \\
\hline
\end{tabular}

Tabel 10. Jumlah Responden Menurut Tingkat Perencanaan Kelompok

\begin{tabular}{ccc}
\hline Perencanaan Kelompok & Jumlah Responden & Prosentase \% \\
\hline Tinggi & 12 & 100 \\
Sedang & - & 0 \\
Rendah & - & 0 \\
\hline Jumlah & 12 & 100 \\
\hline
\end{tabular}

Tabel 11. Jumlah Responden Menurut Tingkat Pengawasan Kelompok

\begin{tabular}{ccc}
\hline Efektifitas Kelompok & Jumlah Responden & Prosentase \% \\
\hline Tinggi & 12 & 100 \\
Sedang & - & 0 \\
Rendah & - & 0 \\
\hline Jumlah & 12 & 100 \\
\hline
\end{tabular}




\section{Pengawasan kelompok}

Jumlah responden menurut tingkat pengawasan kelompok dapat dilihat pada Tabel 11. Tabel 11 menunjukan bahwa seluruh anggota kelompok berada pada kategori tinggi dengan prosentasi mencapai $100 \%$. Hal ini membuktikan bahwa pengawasan kinerja kelompok biasanya dilakukan setiap kali adanya suatu pertemuan dengan diikuti oleh seluruh anggota kelompok.

\section{Hak dan Kewajiban Anggota Kelompok}

Hak dan kewajiban anggota ialah anggota berkewajiban melaksanakan kegiatan dalam rangka meningkatkan kesejahteraan masyarakat. Dari Tabel 12 menunjukan bahwa kategori tinggi mencapai $100 \%$. Hal ini membuktikan bahwa setiap anggota kelompok tani LM3 Model Anugerah berkewajiban untuk melaksanakan kegiatan dalam masyarakat dan berhak memberikan pendapat disetiap pertemuan kelompok.

\section{Hak dan Kewajiban Pemimpin/Pengurus}

Hak dan kewajiban pimpinan/pengurus ialah pengurus berhak mengambil keputusan dalam suatu pertemuan yang diadakan kelompok,dan pengurus berkewajiban membina anggota kelompok tani melayani anggota dengan sebaik-baiknya, dan melaksanakan tugas sesuai dengan tanggug jawab dari pimpinan. Jumlah responden menurut hak dan kewajiban pemimpin kelompok dapat dilihat pada Tabel 13.

Tabel 12. Jumlah Responden Menurut Hak dan Kewajiban Anggota Kelompok

\begin{tabular}{ccc}
\hline $\begin{array}{c}\text { Hak dan Kewajiban } \\
\text { Anggota Kelompok }\end{array}$ & Jumlah Responden & Prosentase \% \\
\hline Tinggi & 12 & 100 \\
Sedang & - & 0 \\
Rendah & - & 0 \\
\hline Jumlah & 12 & 100 \\
\hline
\end{tabular}

Tabel 13. Jumlah Responden Menurut Hak dan Kewajiban Pemimpin Kelompok

\begin{tabular}{ccc}
\hline $\begin{array}{c}\text { Hak dan Kewajiban } \\
\text { pemimpin Kelompok }\end{array}$ & Jumlah Responden & Prosentase \% \\
\hline Tinggi & 12 & 100 \\
Sedang & - & 0 \\
Rendah & - & 0 \\
\hline Jumlah & 12 & 100 \\
\hline
\end{tabular}


Berdasarkan Tabel 13 menunjukan bahwa seluruh anggota kelompok berada pada kategori tinggi mencapai 100\%, hal ini menunjukan bahwa pimpinan kelompok berkewajiban untuk membina dan melayani seluruh anggota kelompok tani LM3 Model Anugerah. Hasil analisis korelasi dari dinamika kelompok dan pendapan kelompok Menunjukan bahwa, kelompok tani ternak LM3 Model Anugerah mempunyai hubungan.ini dibuktikan lewat perhitungan dengan menggunakan analisis korelasi pearson dengan uji signifikansi koofisien korelasi, di peroleh hasil $r_{\text {hitung }}$ sebesar 0,67 dan nilai $t_{\text {hitung }}$ sebesar 2,861 melebihi dari nilai $\mathrm{t}$ tabel sebesar 1,812. Uji hipotesis mengatakan Ho ditolak dan $\mathrm{Ha}$ diterima hal ini menunjukan bahwa terdapat hubungan yang cukup erat antara dinamika kelompok tani ternak sapi dengan pendapatan usaha ternak sapi.

\section{KESIMPULAN}

Berdasarkan hasil dan pembahasan kelompok tani ternak sapi LM3 Model Anugerah secara keseluruhan memiliki dinamika kelompok yang tinggi, Sehingga mengakibatkan tambahan terhadap pendapatan usaha ternak sapi.

\section{DAFTAR PUSTAKA}

Kementan, 2013. Peraturan Menteri Pertanian Nomor 82/Permentan/OT.140/8/2013 Tentang Pedoman Pembinaan Kelompoktani Dan Gabungan Kelompoktani. Kementerian Pertanian, Jakarta.

Mardikanto T. 1993. Penyuluhan Pembangunan Pertanian. Sebelas Maret University Press, Surakarta.

Nawawi, H., 1995. Metode Penelitian Bidang Social. Gadjah Mada Universitas Press, Jakarta

Sigarimbun, M, Dan Effendi, S. 1999. Metode Penelitian Survey. Lembaga Penelitian Dan Penerangan Ekonomi Dan Sosial.Jakarta

Sugeng, B.Y., 2008. Sapi Potong.Penebar Swadaya. Jakarta.

Suhardiyono. 1992. Penyuluhan Penyuluh Pertanian. Erlangga. Jakarta

Trimo, STP. 2006. Evaluasi Penyuluhan Pertanian Permasalahan Dan Upaya Pemecahan di Kecamatan Bayudono Kabupaten Boyolali 